\title{
ERRATUM
}

Balázs Koroknai · Péter Horváth · Kadosa Balogh István Dunkl

\section{Alpine metamorphic evolution and cooling history of the Veporic basement in northern Hungary: new petrological and geochronological constraints}

Published online: 1 June 2001

(C) Springer-Verlag 2001

\section{Int J Earth Sciences (2001)}

DOI 10.1007/s005310000185

Abstract section: There was a mistake in the third sentence. The sentence should read:

Thermobarometric calculations yield lower amphibolite facies peak conditions (ca. $550 \pm 30^{\circ} \mathbf{C}$ and $9 \pm 1$ kbar) for the Eoalpine metamorphic event.

The online version of the original article can be found at http://dx.doi.org/10.1007/s005310000185

B. Koroknai $(\varangle)$

Geological Research Group, Hungarian Academy of Sciences,

Múzeum krt. 4/A, 1088 Budapest, Hungary

e-mail: koroknai@iris.elte.hu

P. Horváth

Laboratory for Geochemical Research,

Hungarian Academy of Sciences, Budaörsi út 45,

1112 Budapest, Hungary

K. Balogh

Institute of Nuclear Research, Hungarian Academy of Sciences, Bem tér 18/c, 4026 Debrecen, Hungary

I. Dunkl

Laboratory for Geochemical Research,

Hungarian Academy of Sciences, Budaörsi út 45,

1112 Budapest, Hungary

Present address:

István Dunkl, Institut für Geologie und Paläontologie,

University of Tübingen, Sigwart Str. 10, 72076 Tübingen,

Germany 